\title{
The Effect of $\mathrm{X}$-Radiation in vivo on Protein and Nucleoprotein Metabolism in the Rat
}

\author{
By J. E. RICHMOND,* MARGERY G. ORD AND L. A. STOCKEN \\ Department of Biochemistry, University of Oxford
}

(Received 17 September 1956)

A satisfactory explanation is not yet available of the difference in sensitivity of various animal tissues to ionizing radiations. The rule of Bergonie \& Tribondeau (1906) relates sensitivity to mitotic activity, and in general it is obeyed, but the behaviour of the lymphocytes is anomalous and that of thymus questionable. We have considered the possibility (Ord \& Stocken, 1955, 1956a) that the damage may depend on the relative volumes and metabolic activities of the cytoplasm and the nucleus; similar ideas have been expressed by Schjeide, Mead \& Myers (1956). It is, however, not easy to design unequivocal experiments to decide this point, and we have therefore concerned ourselves with a comparison of the effect of X-radiation on the incorporation of phosphate, glycine and lysine into subcellular fractions of several rat tissues.

Some studies have been carried out on the incorporation of amino acids into nucleoprotein (Allfrey, Daly \& Mirsky, 1955a), but the effect of radiation in vivo on the incorporation has not been examined nor has a comparison been made of the simultaneous incorporation of phosphate into nucleic acid and an amino acid into the histone. We therefore decided to investigate this in a radiosensitive and non-sensitive tissue and chose thymus and liver as examples.

Since comparatively few studies have been made of protein metabolism in several organs in the same animal after irradiation, the experiments were extended to include a comparison of the rates of incorporation of lysine and glycine into the proteins of spleen, pancreas and bone marrow, which differ in their radiosensitivity and their capacity to form proteins. Such an investigation might give some indications as to the site or sites of the radiation lesion in the cell and perhaps allow a correlation of metabolic disturbance with the radiosensitivity of the various organs.

\section{METHODS}

Animals. Eight male litter-mates of the laboratory strain of Wistar rats weighing approx. $75 \mathrm{~g}$. were used in each experiment. Four of the animals served as controls. All rats

\footnotetext{
* Commonwealth Fund Fellow, New York.
}

were fasted for $2.5 \mathrm{hr}$. before administration of the isotopes, and were killed by decapitation $2 \mathrm{hr}$. afterwards.

Irradiation. X-Radiation was carried out in vivo at the M.R.C. Radiobiological Research Unit, Harwell. The characteristics of the radiation were: half-value layer $2.5 \mathrm{~mm}$. Cu, peak voltage $250 \mathrm{kv}$. at $14 \mathrm{~mA}$. The rats received $1000 \mathrm{r}$. total body radiation in $14 \mathrm{~min} .38 \mathrm{sec}$.

\section{Administration of labelled isotopes}

Phosphate. Carrier-free sodium [ $\left.{ }^{32} \mathrm{P}\right]$ phosphate was obtained from The Radiochemical Centre, Amersham, and was brought to $\mathrm{pH} 7$ before use. The animals were injected intramuscularly with $50 \mu \mathrm{c} / 100 \mathrm{~g}$. body wt. immediately after irradiation.

Amino acids. An enzymic hydrolysate of casein was obtained from Benger's Ltd., Holmes Chapel, Cheshire. $\left[2-{ }^{14} \mathrm{C}\right]$ Glycine was purchased from The Radiochemical Centre, Amersham. Uniformly labelled L- $\left[{ }^{14} \mathrm{C}\right]$ lysine was prepared by growing Chlorella in a ${ }^{14} \mathrm{CO}_{2}$ atmosphere as described by Dutton (1956), and the lysine isolated from an enzymic hydrolysate by the chromatographic method of Hirs, Moore \& Stein (1952). A solution was made to contain $800 \mathrm{mg}$. of casein hydrolysate, $15 \mathrm{mg}$. of cysteine and $195 \mu \mathrm{C}$ of glycine (specific activity $50 \mu \mathrm{c} / \mathrm{mg}$.) in $5 \mathrm{ml}$.; $20 \mu \mathrm{c} / 100 \mathrm{~g}$. body wt. was injected intraperitoneally immediately after the injection of ${ }^{32} \mathrm{P}$. Labelled lysine was substituted for labelled glycine in the second experiment.

\section{Preparation of samples. Expt. 1}

Two hours after administering the isotopes, the animals were decapitated and the blood was collected in heparinized dishes. The plasma was separated and the specific activities of the inorganic phosphate and plasma proteins were determined as a reference for the incorporation experiments. Pancreas, liver, spleen and the long bones were quickly excised and frozen in liquid oxygen.

Thymus. The whole thymus was taken and deoxyribonucleic acid nucleoprotein prepared as described by Crampton, Lipshitz \& Chargaff (1954). The nucleoprotein was caused to dissociate by $2 \cdot 6 \mathrm{M}-\mathrm{NaCl}$ and the deoxyribonucleic acid (DNA) removed by precipitation with ethanol. After deproteinizing twice more with sodium dodecyl sulphate (Chargaff, 1955) the DNA was extracted as described by Deluca, Rossiter \& Strickland (1953). Ionexchange chromatography was used to separate ${ }^{32} \mathrm{P}$-labelled deoxyribonucleotides and paper electrophoresis for the ${ }^{14} \mathrm{C}$-labelled nucleotides. In both cases about $80 \%$ of the radioactivity was recovered and no evidence could be obtained of non-nucleotide contamination.

The supernatant from the first deproteinization was dried in a frozen state, redissolved in water and, after dialysis, 
treated by the method of Daly \& Mirsky (1955) for the isolation of the histone fractions.

Liver, pancreas and spleen. Nuclei were prepared by the method of Dounce, Witter, Monty, Pate \& Cottone (1955) and the nucleoprotein as well as DNA were isolated according to the procedure of Crampton et al. (1954). The histone fraction was obtained by the modified method of Daly \& Mirsky (1955) as in the experiment with thymus, except that it was not fractionated. Mitochondrial and microsomal fractions were obtained by the procedure of Dounce et al. (1955) and the proteins were prepared, dialysed and analysed by the methods of Littlefield, Keller, Gross \& Zamecnik (1955).

Blood and bone marrow. Haemoglobin was prepared from washed cells by the procedure of Drabkin (1949). Plasma proteins were prepared by the methods of Miller, Bly, Watson \& Bale (1951). Bone-marrow proteins were obtained from a bone-marrow supernatant (Richmond, Altman \& Salomon, 1951) by precipitation with $2 \cdot 8 \mathrm{M}$ phosphate buffer, pH 6.8 (Drabkin, 1949). The precipitate was washed exhaustively with ethanol-ether-chloroform and was found to be about $90 \%$ haemoglobin on the basis of the haematin content.

\section{Preparation of samples. Expt. 2}

In the second experiment the liver, as well as the thymus, was processed without delay. The methods were the same as in the first experiment except that the medium of Barnes, Esnouf \& Stocken (1956) was used in the isolation of nuclei, mitochondria and microsomes. Thymus deoxynucleoprotein was obtained from the nuclei as in Expt. 1, and the histones were liberated as before. The incompletely deproteinized DNA obtained at the $\mathrm{NaCl}$-ethanol stage was then shaken overnight in water, $\mathrm{pH} 7 \cdot 0$, at $2^{\circ}$, and the insoluble residue separated to give the residual DNA-protein fraction. The DNA was deproteinized, extracted and estimated as in Expt. 1. Spleen and bone marrow were not investigated.

\section{Measurement of radioactivity}

The ${ }^{32} \mathbf{P}$ activity was measured as previously described (Ord \& Stocken, 1956a). For the ${ }^{14} \mathrm{C}$ measurements samples of the order of $500 \mu \mathrm{g}$. were weighed on aluminium planchettes $1.5 \mathrm{~cm}$. in diameter and spread over the entire surface with solvent. The dried samples were then counted in a helium gas-flow counter as described by Garrow \& Piper (1955). A background count was determined at least twice each day and the plateau for this counter was checked at least once each day with the use of a standard. The efficiency of the counter was approximately $35 \%$. Sufficient counts were recorded to give a counting error of less than $3 \%$. Duplicate samples gave reproducible counting rates within $5 \%$.

\section{RESULTS}

The simultaneous uptake of phosphate and of amino acid into nuclear material has been studied with two amino acids which have different anabolic fates. Glycine was used since it takes part both in DNA and in protein synthesis; lysine on the other hand is metabolically less versatile and does not find its way into DNA.

${ }^{32} \mathrm{P}$ phosphate and $\left[{ }^{2-14} \mathrm{C}\right]$ glycine or $\left[{ }^{14} \mathrm{C}\right]$ lysine were injected and the control and irradiated animals killed $2 \mathrm{hr}$. later. The specific activity of the phosphorus in DNA was referred to that of plasma inorganic phosphate but since we had no similar standard for the amino acids and since there was no difference in the specific activities of the plasma proteins of normal and irradiated rats the results were expressed as counts/min./mg. of material.

The inhibition of ${ }^{32} \mathrm{P}$ incorporation into thymus DNA (Table 1) was the same as that previously obtained under the same conditions (Ord \& Stocken, $1956 a)$, and the reduction in glycine uptake confirms the earlier experiments of Harrington \& Lavik (1955), who showed that 100 r. X-radiation lowered the incorporation of formate $24 \mathrm{hr}$. after exposure. The inhibition seemed to be rather greater with glycine than with phosphorus but more evidence would be required to substantiate this.

- The data in Table 1 indicate that all thymus nuclear fractions investigated were adversely affected by irradiation, and there was little difference in the response between the fractions. Mitochondria and microsomal supernatant (soluble) proteins were not altered by irradiation, while there was a slight decrease in the incorporation of lysine into the microsomal-protein fraction. It is interesting to note that the histone fractions of thymus had the highest specific activity of all the fractions studied in this tissue at this time interval. In the experiments with radioactive glycine, the 'arginine-rich', 'lysine-rich' and the histone fraction precipitated with saturated $\mathrm{NaCl}$ had about the same specific radioactivities, although their glycine contents are different (Allfrey et al. 1955a).

Table 1. Effect of $X$-radiation on the incorporation of carbon and phosphorus precursors into fractions obtained from rat thymus

All results are expressed as means \pm standard deviation. Each group consisted of four animals.

Fraction Control Irradiated Glycine incorporation (counts/min./mg.)

DNA

Total histone $376 \pm 8 \quad 91 \pm 11$

'Arginine rich' histone

'Lysine rich' histone

Acid-insoluble residue

$473 \pm 33$

$459 \pm 31$

of histone fraction

227

$217 \pm 2$

$276 \pm 31$

106

$$
\text { Lysine incorporation (counts/min./mg.) }
$$

Total histone

Residue DNA-protein

Mitochondria

Microsomes

Microsomal supernatant

$2064+242$

$1342 \pm 67$

$285 \pm 57$

$1153 \pm 110$

$771 \pm 160$

$154 \pm 23$

$1629 \pm 115$

$1128 \pm 34$

$598 \pm 46$

$1629 \pm 50$

Phosphorus incorporation

(relative to specific activity of plasma inorganic $\mathrm{P} \times 10^{2}$ )

DNA (glycine experiment)

DNA (lysine experiment)

$1 \cdot 8 \pm 0 \cdot 2$

$4 \cdot 5 \pm 0 \cdot 2$

$1 \cdot 1 \pm 0 \cdot 4$ 
Similarly, under the conditions of our experiments the activity of the total histones of liver (Table 2) was always greater than that of the residual protein. Allfrey et al. (1955a), however, using $\left[{ }^{15} \mathrm{~N}\right]$ glycine under different conditions, found that incorporation in vivo into liver, pancreas and kidney nucleohistones of mice was very low compared with that into the residual protein fraction. The ${ }^{14} \mathrm{C}$ activity of our rat-liver histones after administration

Table 2. Effect of $X$-radiation on the incorporation of carbon and phosphorus precursors into fractions obtained from rat liver

Results are mean values of four animals \pm S.D.

Fraction Control Irradiated

Glycine incorporation (counts/min./mg.)

DNA

\begin{tabular}{|c|c|}
\hline $\begin{array}{l}131 \pm 22 \\
995 \pm 175 \\
547 \pm 88\end{array}$ & $\begin{array}{c}152 \pm 46 \\
1278 \pm 154 \\
629 \pm 72\end{array}$ \\
\hline $\begin{aligned} 984 & \pm 115 \\
966 & \pm 130 \\
743 & \pm 80 \\
1082 & \pm 74\end{aligned}$ & $\begin{array}{r}945 \pm 63 \\
1022 \pm 11 \\
903 \pm 10 \\
1229 \pm 10\end{array}$ \\
\hline $338 \pm 6$ & $737 \pm$ \\
\hline
\end{tabular}

Total histone

Acid-insoluble residue of histone fraction

Mitochondria

Microsomes

Microsomal supernatant

Deoxycholate-soluble

portion of microsomes

Deoxycholate-insoluble

portion of microsomes

Lysine incorporation (counts/min./mg.)

Total histone

$1544 \pm 127 \quad 1769 \pm 130$

Residue DNA-protein

Mitochondria

Microsomes

Microsomal supernatant

$723 \pm 85$

$941 \pm 65$

$581 \pm 90$

$1453 \pm 148$

$760 \pm 62$

$1076 \pm 69$

$761 \pm 140$

$1749 \pm 81$

Phosphorus incorporation

(relative to specific activity of plasma inorganic $\mathrm{P} \times 10^{2}$ ) DNA (lysine experiment) of glycine was higher than that of thymus; with lysine little difference was detectable. Amino acid uptake into the liver nuclear fractions was if anything slightly increased, as has been reported for acetate incorporation into liver protein by Hevesy $(1949 a)$ and for phenylalanine into a number of liver-protein fractions by Butler, Cohn \& Crathorn (1956). Glycine incorporation into DNA was unaffected although ${ }^{32} \mathrm{P}$ uptake was reduced.

Amino acid incorporation into the proteins of pancreas (Table 3) was more variable but did not show any striking changes after irradiation. The soluble proteins had the highest observed specific activity of this organ as well as of the entire animal.

Table 4 contains the data on blood and bone marrow. The incorporation of amino acids into the plasma proteins and circulating haemoglobin was not measurably altered by irradiation. Fractionation of the plasma proteins failed to show a radiation lesion. There was little change in the amount of glycine incorporated into bone-marrow proteins after irradiation.

\section{DISCUSSION}

It is conceivable in work involving the disruption of cells followed by the isolation of subcellular fractions that these operations in themselves induce a distribution of the cellular components different from that of the intact cell (Dounce, 1955; Allfrey, Mirsky \& Stern, 1955c), and this possibility cannot be ruled out in the present work. However, several deductions may be made from the results. In the thymus, the histone fraction contained more radioactivity than any other fraction. The radioactivity of this fraction could only be diluted by other

Table 3. Effect of $X$-radiation on the incorporation of amino acids into rat pancreas

Results are mean values of four animals \pm S.D.

\begin{tabular}{|c|c|c|c|c|}
\hline \multirow[b]{2}{*}{ Fraction } & \multicolumn{2}{|c|}{$\begin{array}{l}\text { Glycine incorporation } \\
\text { (counts/min./mg.) }\end{array}$} & \multicolumn{2}{|c|}{$\begin{array}{l}\text { Lysine incorporation } \\
\text { (counts/min./mg.) }\end{array}$} \\
\hline & Control & Irradiated & Control & Irradiated \\
\hline $\begin{array}{l}\text { Histone } \\
\text { Mitochondria } \\
\text { Microsomes } \\
\text { Microsomal supernatant }\end{array}$ & $\begin{aligned} 576 & \pm 72 \\
1728 & \pm 128 \\
1438 & \pm 60 \\
3034 & \pm 390\end{aligned}$ & $\begin{aligned} 450 & \pm 45 \\
1711 & \pm 301 \\
1686 & \pm 300 \\
3236 & \pm 356\end{aligned}$ & $\begin{aligned} & 220 \\
& 1579 \pm 265 \\
& 1235 \pm 195 \\
& 10310 \pm 1400\end{aligned}$ & $\begin{aligned} 113 \\
1596 \pm 380 \\
1224 \pm 335 \\
10265 \pm 819\end{aligned}$ \\
\hline
\end{tabular}

Table 4. Effect of $X$-radiation on the incorporation of amino acids into rat haemoglobin and plasma proteins

Results are mean values of four animals \pm s.D.

Substance

Control

Glycine incorporation (counts/min./mg.)

Haemoglobin, blood

Bone-marrow proteins (haemoglobin)

Total plasma proteins

$$
\begin{aligned}
163 & \pm 15 \\
1685 & \pm 100 \\
667 & \pm 69
\end{aligned}
$$

Irradiated

$157 \pm 34$

$1476 \pm 100$

$686 \pm 31$

Lysine incorporation (counts/min./mg.)

Total plasma proteins $\quad 2016 \pm 148$ 
fractions, unless of course there is selective absorption of a highly active fraction on the deoxyribonucleic acid-protein with similar chemical properties and the same solubility characteristics as the deoxyribonucleoprotein and the derived histones. If dissociation followed by re-association with non-specific proteins occurred in the process of isolation, the data obtained indicate that this process is restricted to intranuclear interactions and the effects observed after irradiation should be real unless irradiation specifically induces adsorption.

Protein synthesis as well as deoxyribonucleic acid synthesis, in thymus nuclei seems to be inhibited by radiation. The latter finding has been reported earlier (Hevesy, 1949 $a$ ), as has the inhibition of ${ }^{32} \mathrm{P}$ phosphate uptake into nuclear ribonucleic acid (RNA) (Ord \& Stocken, 1956b). Even though fractions isolated from thymus nuclei, in addition to histone, exhibited a depression in amino acid incorporation after irradiation, the possibility of these ill-defined proteins being mixtures of denatured histones has not been eliminated. Alternatively, the synthesis of these fractions may be directly related to (Allfrey, Mirsky \& Osawa, 1955b), or a resultant of, histione formation. Butler et al. (1956) have reported very recently that the incorporation of amino acids into total thymus proteins is not altered after $500 \mathrm{r}$. The latter observation of these investigators is not in disagreement with the present work inasmuch as the histone fractions are not the greater part of the proteins of thymus, and although there is a lowered uptake of ${ }^{32} \mathrm{P}$ into cytoplasmic RNA incorporation into mitochondrial and soluble proteins is unaffected.

Several investigators have studied the incorporation of isotopic amino acids into the proteins of the subcellular fractions of liver from adult animals (Brunish \& Luck, 1952; Allfrey et al. 1955a). The rate of incorporation into the histone fraction, by comparison with other fractions, is faster in the present experiment than has been reported previously. This difference is perhaps due to the greater incorporation in growing rats. It is noteworthy that $2 \mathrm{hr}$. after administering the amino acids, the histone fraction had about the same level of radioactivity as the soluble proteins. Since only one time period was done, no inference can be made as to the likelihood of some of these fractions having a precursor relationship. Fractionation of the deoxycholate-soluble and -insoluble portions showed that the soluble fractions contained more of the radioactivity than the insoluble fraction, which was about the same in the control and irradiated groups.

An increase in the incorporation of protein precursors into liver proteins after irradiation has been observed previously by Hevesy $(1949 b)$ and by Butler et al. (1956). A very slightly increased incorporation into the fractions was found in the present experiments, with the exception, perhaps, of the nuclear and mitochondrial fractions.

The results for ${ }^{32} \mathrm{P}$ and glycine incorporation into DNA had a wider scatter than those for thymus but there appears to be some difference in the effects of radiation on the uptake of these tracers into liver DNA. Although ${ }^{32} \mathrm{P}$ uptake into DNA is reduced $2 \mathrm{hr}$. after $1000 \mathrm{r}$., incorporation into nuclear and cytoplasmic RNAs is unaffected or slightly increased (Ord \& Stocken, 1956a; Sherman \& Almeida, 1956), and glycine uptake was unaffected. Similar discrepancies have been reported in the inhibition of the uptake of various carbon precursors into DNA of rat thymus $24 \mathrm{hr}$. after $100 \mathrm{r}$. (Harrington \& Lavik, 1955). The reason for these inconsistences is at present unknown, but it is possible that there is some contamination of the DNA with radioactive protein. Recoveries of ${ }^{14} \mathrm{C}$ in nucleotides of thymus DNA seemed to exclude this explanation, but with liver lack of material did not allow similar experiments to be performed. The expected contamination after detergent deproteinization does not usually exceed $0.5 \%$ (Frick, 1954), but since in addition to this we subsequently carried out the Hammarsten-extraction procedure it seems unlikely that the specific activity of the DNA can be greatly in error.

Amino acid incorporation into the plasma proteins followed the same general pattern as liver proteins in the irradiated and control groups in confirmation of the observation of Miller (private communication), and similar results were obtained for pancreas. The fluctuation of the levels of radioactivity in the fractions isolated from pancreas is perhaps a resultant of varying degrees of starvation and stimulation of the gland in response to feeding. These results show that pancreas has the capacity to form considerable quantities of proteins, as has been observed by others isolating distinct proteins rather than mixtures of fractions (Hokin, 1956; Daly, Allfrey \& Mirsky, 1955). It has been shown recently that amylase synthesis is augmented by radiation (Hokin \& Hokin, 1956).

The specific activity of the circulating haemoglobin was about the same in both groups. How ever, there was not a marked decrease in the amount of amino acids incorporated into the proteins precipitated from a bone-marrow supernatant with 2.8 M-phosphate buffer.

Results obtained for spleen were qualitatively similar to those of liver and pancreas after irradiation. Because of the marked changes in spleen during the first day after irradiation (Kallman \& Kohn, 1955) it is difficult to interpret the data procured with this organ. Work is in progress in this laboratory to characterize some of the changes that occur in this organ at short time intervals after irradiation. 
The biochemical difference in radiosensitivity of rat tissues is well illustrated when the effects of $\mathrm{X}$-radiation on incorporation of amino acids into DNA and the histone fractions of liver and thymus are considered. In thymus, inhibition of glycine uptake into DNA is accompanied by a marked reduction in glycine and lysine incorporation into the histones, whereas in liver there is little change, or even an enhancement of incorporation into the nucleoproteins. The disturbance in nucleic acid and histone metabolism shown by thymus after exposure, at the same time that certain highly organized, energy-dependent cytoplasmic functions are undisturbed, contributes to the suggestion that the nucleus is the prime site of the metabolic lesion produced by $\mathrm{X}$-radiation.

\section{SUMMARY}

1. The incorporation of labelled glycine, lysine and phosphate into various fractions of rat tissue has been examined at $2 \mathrm{hr}$. after $1000 \mathrm{r}$. X-radiation.

2. The uptake of ${ }^{32} \mathrm{P}$ and $\left[2{ }^{14} \mathrm{C}\right] \mathrm{glycine}$ by ratthymus DNA was reduced by X-radiation.

3. The incorporation of $\left[2-{ }^{14} \mathrm{C}\right] \mathrm{glycine}$ and $\left.{ }^{14} \mathrm{C}\right]$ lysine into thymus nucleoproteins was also lowered; uptake into liver nucleoproteins was not affected.

4. Incorporation into cytoplasmic proteins of thymus, liver and pancreas was unaffected or slightly increased.

5. The difference in radiosensitivity between thymus and liver is discussed.

We are grateful to Mr M. J. Corp of the M.R.C. Radiobiological Research Unit, Harwell, for irradiation of the animals and to Dr C. E. Dalgleish and Dr R. W. Dutton for collaboration in the preparation of the ${ }^{14} \mathrm{C}$-labelled lysine. We also thank Mr J. A. Morris for skilled technical assistance. One of us (J.E.R.) is indebted to The Commonwealth Fund for a Fellowship.

\section{REFERENCES}

Allfrey, V. G., Daly, M. M. \& Mirsky, A. E. (1955a). J.gen. Physiol. 38, 415.

Allfrey, V. G., Mirsky, A. E. \& Osawa, S. (1955b). Nature, Lond., 176, 1042.
Allfrey, V. G., Mirsky, A. E. \& Stern, H. (1955c). Advanc. Enzymol. 16, 411.

Barnes, D. W. H., Esnouf, M. P. \& Stocken, L. A. (1956). Proc. 5th Int. Congr. Radiobiol. (in the Press).

Bergonie, J. \& Tribondeau, L. (1906). C.R. Acad.Sci., Paris, 143, 983.

Brunish, R. \& Luck, J. M. (1952). J. biol. Chem. 198, 621.

Butler, J. A. V., Cohn, P. \& Crathorn, A. R. (1956). Proc. 5th Int. Congr. Radiobiol. (in the Press).

Chargaff, E. (1955). Nucleic Acids, vol. 1, p. 307. New York: Academic Press.

Crampton, C. F., Lipshitz, R. \& Chargaff, E. (1954). J. biol. Chem. 206, 499.

Daly, M. M., Allfrey, V. G. \& Mirsky, A. E. (1955). J.gen. Physiol. 39, 207.

Daly, M. M. \& Mirsky, A. E. (1955). J. gen. Physiol. 38, 405.

Deluca, H. A., Rossiter, R. J. \& Strickland, K. P. (1953). Biochem. J. 55, 193.

Dounce, A. L. (1955). Nucleic Acids, vol. 2, p.93. New York : Academic Press.

Dounce, A. L., Witter, R. F., Monty, K. J., Pate, S. \& Cottone, M. A. (1955). J. biophys. biochem. Cytol. 1, 139.

Drabkin, D. L. (1949). Arch. Biochem. 21, 224.

Dutton, R. W. (1956). Biochem. J. 62, 382.

Frick, G. (1954). Biochim. biophys. Acta, 13, 374.

Garrow, R. \& Piper, E. A. (1955). Biochem. J. 60, 527.

Harrington, H. \& Lavik, P. S. (1955). Arch. Biochem. Biophys. 54, 6.

Hevesy, G. (1949a). Nature, Lond., 163, 869.

Hevesy, G. $(1949 b)$. Nature, Lond., 164, 269.

Hirs, C. H. W., Moore, S. \& Stein, W. H. (1952). J. biol. Chem. 195, 669.

Hokin, M. R. (1956). J. biol. Chem. 219, 77.

Hokin, M. R. \& Hokin, L. E. (1956). J. biol. Chem. 219, 85.

Kallman, R. F. \& Kohn, H. I. (1955). Radiation Res. 3, 77.

Littlefield, J. W., Keller, E. B., Gross, J. \& Zamecnik, P. C. (1955). J. biol. Chem. 217, 111.

Miller, L. L., Bly, C. F., Watson, M. L. \& Bale, W. F. (1951). $J$. exp. Med. 94, 431.

Ord, M. G. \& Stocken, L. A. (1955). Rep. 3rd Int. Congr. Biochem., Brussels, p. 491.

Ord, M. G. \& Stocken, L. A. (1956a). Biochem. J. 63, 3.

Ord, M. G. \& Stocken, L. A. (1956b). Proc. 5th Int. Congr. Radiobiol. (in the Press).

Richmond, J. E., Altman, K. I. \& Salomon, K. (1951). J.biol. Chem. 190, 817.

Schjeide, O. A., Mead, J. F. \& Myers, L. S. (1956). Science, 123, 1020.

Sherman, F. \& Almeida, A. B. (1956). Proc. 5th Int. Congr. Radiobiol. (in the Press). 